ISSN 1991- 8690

website :http:// jsci.utq.edu.iq

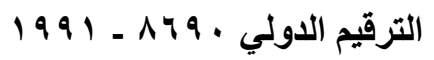

Email: utjsci@utq.edu.iq

\title{
Estimation of gaseous pollutants emitted from Al-Najybia Power station in Basra Asia S.Abdullah ${ }^{(1)}$ Hussien H. Hussien ${ }^{(2)}$ \\ ${ }^{(1)}$ Dept of Pharmacology and Toxicology. College of Pharmacy. Basra \\ ${ }^{(2)}$ Dept of Pharmaceutical Chemistry. College of Pharmacy. Basra E-mail: asia_abdullah65@yahoo.com
}

\section{$\underline{\text { Abstract }}$}

The objective of the present study was to estimate selected gaseous pollutants generated from Al- Najybia power station in Basra, south of Iraq. The highest concentration was found is carbon monoxide, estimated at $18.4 \mathrm{ppm}$ followed by nitrogen dioxide 7.01E-03 ppm and 8.14E-04 ppm for hydrogen sulphide gases estimated in the area of 1 kilometre away from Al- Najybia power station. The concentrations of these toxic gases were decreased as we move away from Al- Najybia station. However, the concentrations in the station 4 which is 4 kilometre away were found to be high compared to the normal concentrations of these gases in the atmospheric air.

الخلاصة

تهدف هذه الدراسة الى تعيين مستويات بعض الغازات المنبعثة من محطة كهباء النجييية كمؤشر على مدى تلوث الهواء الجوب بهذه الغازات السامة

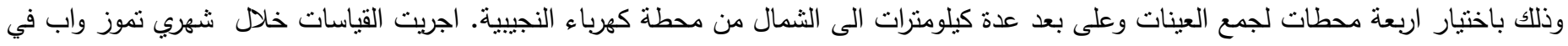

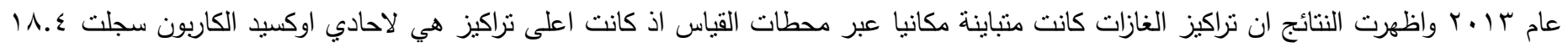

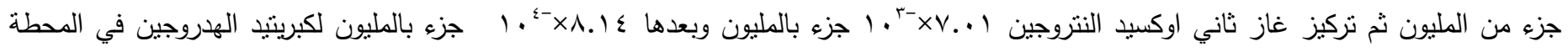
القريبة من محطة كهرباء النجييية. وكانت تراكيز الغازات في محطة القياس البعيدة عن محطة كهرباء النجييية عالية مقارنة بالتراكيز الطبيعية لهذه الغازات

\section{Introduction}

Atmospheric pollution can be defined as "the presence of pollutant or contaminant substances in the air that interfere with human health or wellbeing, or cause other harmful environmental effects" (Vallero, 2008). Air pollution could be arises naturally by gases from volcanoes and fire, pollen, microbes and dust or industrially from fuel consumption and pollutants released from automobile exhaust as well as gases from domestic waste and particulates (Mousa, 1996). The suggestion that up to 24000 deaths a year are brought forward by air pollution should act as a spur to encourage creative approaches to air quality problems (Megainey, 1999).The quality of air is very important, not only to healthy human life but also for wildlife, vegetation, water, and soil (Schwela, 2000). Though, to understand the atmospheric pollution of a given area, an ambient air quality in that area should be assessed. Air quality can be assessed by measuring the levels of pollutants and lengths of exposure at which specific harms to health and welfare may occur. There are still few studies on air pollution in Basra.
The studies of (Al-Imarah, et al ., 2007; Garabedain, 2008; Al-Saad et al, 2010; Ali et al., 2013 and Douabul, et al .2013 ) are carried out to measure the extent of atmospheric pollution by some industrial emissions in Basra and these studies confirmed the role of these emissions in the air pollution, specially the carbon monoxide gas. Another recent study aimed at the cartographic representation for the concentrations of CO measured 34 different sampling stations in ambient air of Basra and the study revealed that about three quarters of the surveyed areas may be suffered from $\mathrm{CO}$ pollutant (Hassen et al., 2013). This study was carried out in Basra and the study area was Al-Najybia power station which is located in Basra, Southeast Iraq as shown in Figure1. Generally, the variable temperatures, elevated solar radiation, low quantity of rainfalls, and high relative humidity characterize the climate of the study area. The importance of present study lies in the necessity of assessing air quality in the area ambient to Al-Najybia power station; because of the emission of toxic gases is expected in this area. Therefore, constant environmental assessing and monitoring of ambient air quality at the study area in the terms of recommended 
exposure levels of air pollutant concentrations is urgent action.

\section{Materials and Method}

\section{The study area and sampling stations}

Al-Najybia electric generating power station is established in 1959. The station consists of two units to produce electricity $(200 \mathrm{~mW} / \mathrm{h})$. Four sites were selected in the study area. The distances between these sites are almost equal. These sites are 1,2, 3 and 4 kilometres away from Al-Najybia power station, as shown in Figure1. The wind speed during the sample collection was 15-20 kilometres per hour to the north and the temperature was $38 \mathrm{C}^{\circ}$.

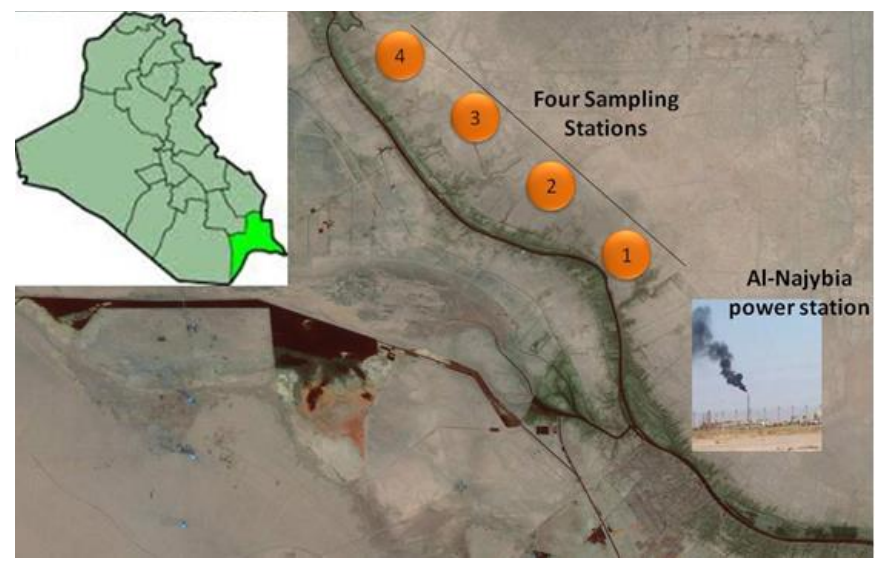

Figure 1: Map showing the study area and the sampling stations for air pollution near to Al Najybia Power Station in Basra city, southern Iraq

\section{Sample Analysis}

Samples were collected in July-August 2013 and measured in triplicate and a variety of gaseous pollutants such as carbon monoxide (CO), nitrogen dioxide $\left(\mathrm{NO}_{2}\right)$ and hydrogen sulfide $\left(\mathrm{H}_{2} \mathrm{~S}\right)$ were measured in this work. $\mathrm{CO}$ and $\mathrm{H}_{2} \mathrm{~S}$ were measured using an Orsat combustion analyzer which consists of a calibrated water-jacketed gas burette linked by glass capillary tubing to two absorption pipettes containing chemical solutions that absorb the gasses required to analyze. The gas is drawn into the burette and flushed through several times. The level of gas in the burette is adjusted to the zero point using the stopcocks that isolate the absorption burettes. The gas is then passed into the caustic burette, left to stand for about two minutes and then withdrawn, isolating the remaining gas via the stopcock arrangements. The process is repeated to ensure full absorption. After leveling the liquid in the bottle and burette, the remaining volume of gas in the burette indicates the percentage of carbon monoxide absorbed. While, the NO2 pollutants were measured by APNA-370, using a cross-flow modulated semi decompression chemiluminescence method, the dry method was used due to its capability for continuously and instantaneously monitoring of gas in its unaltered state as well as its minimal maintenance requirements.Statistical analysis of results was performed with one-way analysis of variance (ANOVA). Comparison between groups was performed with Dunnett's test. Statistical analysis was done using prism software.

\section{Results and Discussion}

In order to estimate the air pollutant gases emitted from Al-Najybia power station in Basra, samples were collected from the atmospheric air of four different stations away from the main station. The results revealed that the highest concentration was found is $\mathrm{CO}$, it was estimated at $18.4 \mathrm{ppm}$ followed by nitrogen dioxide 7.01E-03 ppm and 8.14E-04 ppm for hydrogen sulphide gases estimated in the area of 1 kilometer away from Al- Najybia power station. The lowest concentrations of $\mathrm{CO}, \mathrm{NO}_{2}$ and $\mathrm{H}_{2} \mathrm{~S}$ gases were found in the area of 4 kilometers away from the station, however, the concentrations in this area were found to be high compared to the normal concentrations of these gases in the atmospheric air according to WHO regulations (WHO, 2008 and 2010) and Ministry of Environment (MOE), regulations 2012.Our data showed that the air around al-najybia power station was mainly polluted with $\mathrm{CO}, \mathrm{NO}_{2}$ and $\mathrm{H}_{2} \mathrm{~S}$ gases and the concentrations of these toxic gases were decreased as we move away from the station indicated that this station is the main source of pollution in this area. $\mathrm{CO}$ is a colourless, odourless, no irritating gas produced primarily by incomplete combustion of any carbonaceous fossil fuel. $\mathrm{CO}$ is the leading cause of poisoning mortality in the United States (Tomaszewski, 2002). Nitrogen Oxides (NOx), usually emitted through exhaust gas, have assumed the major responsibility with sulfur dioxide $\left(\mathrm{SO}_{2}\right)$ for acid rain formation, which is harmful to human health and to the environment through acid deposition (van Aardenne et al., 1999; Iwamoto and Hamada, 1991) Health effects associated with air pollution have been relatively high, yet people are exposed to mixtures consisting of multiple pollutants that may have independent or combined effects on human health. Air pollution has both acute and chronic effects on human health, affecting a number of different systems and organs. It ranges from 
minor upper respiratory irritation to chronic respiratory and heart disease, lung cancer, acute respiratory infections in children and chronic bronchitis in adults, aggravating pre-existing heart and lung disease, or asthmatic attacks. In addition, short- and long-term exposures have also been linked with premature mortality and reduced life expectancy, WHO estimates that air pollution is responsible for over a million premature deaths worldwide every year (WHO, 2008).

\section{Conclusion}

It is clear that the verified concentrations of gaseous pollutants in this study are spatially varied due to the impact of emissions released from al-najybia power station depending on the locations of monitored sampling stations. It is concluded that air quality of the study area is not safe. Some gaseous pollutants concentrations, however, may represent a hazard on the public health. Therefore, it is necessary to get more studies with repeated measures across seasons to atmospheric air.

Table 1. Average concentrations ( $\mathrm{ppm} \pm \mathrm{SD}$ ) of the selected gaseous pollutants in the samples collected from the atmospheric air of four different areas away from Al-

Najybia power station in Basra (July-August 2013) compared to the recommended guidelines. Data represent the mean value ( $\mathrm{n}=3$ individual assays)

\begin{tabular}{|c|c|c|c|}
\hline Stations & $\mathrm{CO}(\mathrm{ppm})$ & $\mathrm{NO}_{2}(\mathrm{ppm})$ & $\mathrm{H}_{2} \mathrm{~S}(\mathrm{ppm})$ \\
\hline 1 & $18.4 \pm 2.4$ & $0.007 \pm 0.00046$ & $8.41 \mathrm{E}-04 \pm 9.34 \mathrm{E}-05$ \\
\hline 2 & $6.85 \pm 1.43$ & $0.0033 \pm 4.67 \mathrm{E}-04$ & $3.74 \mathrm{E}-04 \pm 9.34 \mathrm{E}-05$ \\
\hline 3 & $4.05 \pm 1.43$ & $0.00011 \pm 3.00 \mathrm{E}-05$ & $1.21 \mathrm{E}-05 \pm 5.68 \mathrm{E}-06$ \\
\hline 4 & $1.7 \pm 0.7$ & $4.67 \mathrm{E}-05 \pm 4.67 \mathrm{E}-06$ & $5.61 \mathrm{E}-06 \pm 0.00 \mathrm{E}+00$ \\
\hline WH0, 2008 and 2010 & 0.4 & $9.343 \mathrm{E}-07$ & $1.869 \mathrm{E}-07$ \\
\hline
\end{tabular}

A

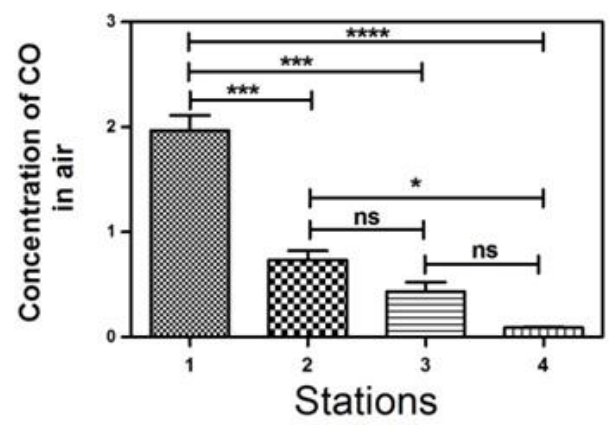

B

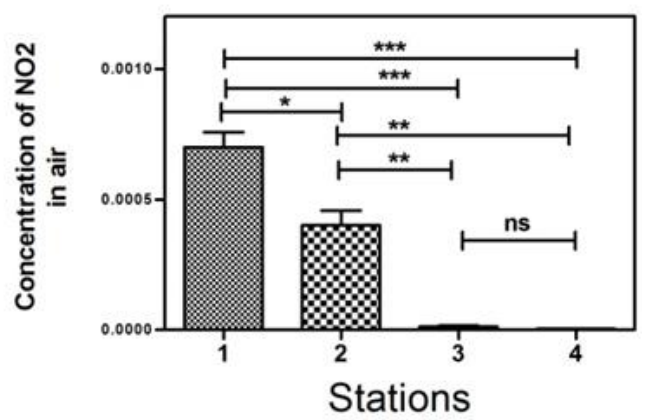

C

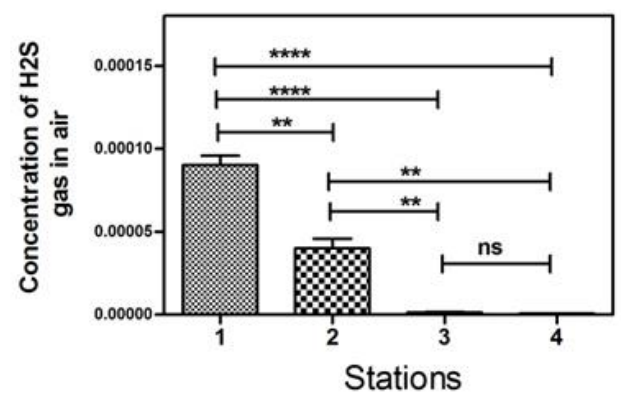

Figure 1: Percentages of (A) Carbon monoxide CO (B) nitrogen dioxide $\mathrm{NO}_{2}$ and (C) hydrogen sulphid $\mathrm{H}_{2} \mathrm{~S}$ gases in the atmospheric air of the study area. Data represent the mean value ( $\mathrm{n}=3$ individual assays). $(* * * * \mathrm{p}<0.0001, * * * \mathrm{p}<0.001, * * \mathrm{p}<0.01$ and $* \mathrm{p}<0.05)$

\section{References}

1- Al-Imarah, F.J.M., Al-Mohameed, R.Sh, J, and Ibraheem S.I. (2007). Extent of atmospheric pollution by some industrial emissions released from petrochemicals and gas liquefier industries in Khor Al- Zubair, J. of Kerbala, Special Issue on the Annual Environment of Meeting of Babylon University, Mar.:1-6.

2- Al-Saad, H.T., Al-Imarah, F.J.M., Hassan, W.F.,Jasim, A.H., Hassan, I.F. (2010). Determination of some trace elements in the fallen dust on Basra. Basrah Journal of Science, 28(2):243-252.

3- Douabul, A.A.Z., Al-Maarofi, S.S., Al-Saad, H.T., and Al-Hassen, Sh.I. (2013). Gaseous pollutants in Basra City, Iraq. Air, Soil and Water Res. (6): 15-21. 
4- Garabedain, S.A.K. (2008). Levels of some trace metals in falling dust of Basra. Mesopotamian Journal of Marine Science. 23(2):279-286.

5- Global Health Observatory Data Repository. Urban outdoor air pollution: burden of disease by country. Geneva: World Health Organization, 2008.

http://apps.who.int/gho/data/node.main.285 (accessed Sept 1, 2012).

6- Hassen A.K., Shukri I.A., Rita S.A. and Moyuad H.Q. A Cartographic Representation to Levels and Impacts of Carbon Monoxide Pollutant in Basra City, Southern Iraq. J.Thi-Qar Science, 2013:4(1):105-115.

7-

8- Iwamoto M, Hamada H. Removal of nitrogen monoxide from exhaust gases through novel catalytic processes. Catalysis Today. 1991; 10(1):57-71.

9-

10- Megainey C. Introduction to environmental protection. In: Bassett WH. Clay's Handbook of Environmental Health. London: E \& FN Spon; 1999:684-703.

11- Mousa,M.A.; Atmospheric Pollution. Dar ElFiker Al-Mooaser, Demascus, Syria.; 1996.

12- Schwela D. Air pollution and health in urban areas. Rev Environ Health. 2000;12(1-2):13-42.

13- Tomaszewski C. Carbon monoxide. In: Goldfrank LR, Flomenbaum NE, Lewin NA, et al, editors. Goldfrank's toxicologic emergencies. 7th edition. New York: McGraw-Hill; 2002. p. 1478-97.

14- Vallero DA. Fundamentals of Air Pollution. 4th ed. London: Elsevier Inc.; 2008.

15- van Aardenne JA, Carmichael GR, Levy H, Streets D, Hordijk L. Anthropogenic NOx emissions in Asia in the period 1990-2020. Atmospheric Environment. 1999;33(4):633-646.

16- WHO (World Health Organization) (2010) WHO guidelines for indoor air quality: selected pollutants, WHO Regional Office for Europe, Bonn: 454. 